\title{
The prediction of undergraduates' self-regulation strategies, motivational beliefs, attitudes towards English, and speaking anxiety on foreign language classroom anxiety
}

\author{
Mehtap Bademcioglu ${ }^{1}$ \\ Hakan Karatas ${ }^{2}$ \\ Atilla Ergin ${ }^{3}$
}

\begin{abstract}
Individual differences are considered as important factors in the language learning process. Apart from individual differences, affective factors such as attitudes and motivation of individuals and their anxiety levels which affect the individuals' language learning directly or indirectly are also believed as significant impacts in this process. Therefore, the purpose of the present study is to examine the relationship between self-regulation strategies, motivational beliefs, attitudes, speaking anxiety and foreign language classroom anxiety and to investigate the predictive power of these variables for foreign language classroom anxiety. The relational model was used in the current study. The research group included 320 male $(65.6 \%)$ and 168 female (34.4\%) English preparatory students at Istanbul Technical University. Attitudes toward English Lesson Scale, Foreign Language Speaking Anxiety Questionnaire, The Motivational Strategies for Learning Questionnaire, and Foreign Language Classroom Anxiety Scale were used as the data collection tool. The statistical methods used for analyses were correlation and multiple regression. The findings indicated that there is a significant positive correlation between foreign language classroom anxiety and self-regulation, test anxiety, and foreign language speaking anxiety. Also, there is significant negative correlation between foreign language classroom anxiety and selfefficacy intrinsic value perception, and attitude towards English. Moreover, self-efficacy, test anxiety, attitude towards English, and foreign language speaking anxiety are predictors of the university students' foreign language classroom anxiety.
\end{abstract}

Keywords: ESL; self-regulation strategies; motivational beliefs; attitude; speaking anxiety; FLCA.

\section{Introduction}

Language which is a vital tool since human existence is defined as the common name of every means of communication used in the transmission of thoughts, emotions and needs in its broadest sense. Also, it is the main tool in interpersonal relations (Kaplan, 2007). In our days, rapid globalization reinforces societies' relations. Thus, many people need to learn foreign languages. According to Dörnyei ve Csizer (2002), learning a foreign language has become a necessity in order to be able to follow scientific developments and to capture international

\footnotetext{
1 Asist. Prof., Yildiz Technical University, Faculty of Education, Educational Sciences, mehtapbademcioglu@gmail.com

2 Assoc. Prof., Yildiz Technical University, Faculty of Education, Educational Sciences, hkaratas@yildiz.edu.tr

${ }^{3}$ Ph.D. Student, Yildiz Technical University, Faculty of Education, Educational Sciences, Atillaergin ist@hotmail.com
} 
Bademcioglu, M., Karatas, H., \& Ergin, A. (2017). The prediction of undergraduates' self-regulation strategies, motivational beliefs, attitudes towards English, and speaking anxiety on foreign language classroom anxiety. Journal of Human Sciences, 14(1), 571-586. doi:10.14687/ihs.v14i1.4132

business opportunities. Today, the number of students who learn German or French as a foreign language decreased. However, English has become a world language (Graham, 2004). Therefore, the researches have focused on learning English as a foreign language and the factors affecting it.

Although there are varies depending upon individual purposes, learners are expected to achieve the targeted level of basic skills such as listening, speaking, reading and writing and to learn the pronunciation and structure of the target language. However, foreign language learning is a complex field because individual differences such as their motivational beliefs, attitudes and expectations, and affective states have different effects on language learning process (Gardner, 1985). Many studies have been conducted so as to determine the role of affective factors in a foreign language learning in recent years. And, attitude, motivation, anxiety, self-esteem, empathy, and self-efficacy are considered as key factors in language learning (Maclntyre \& Gardner 1991; Oxford, 1994; Rossiter, 2003). For instance, the researches which were conducted by Ellis (1994) and Mitchell and Myles (1998) demonstrate that student attitudes affect their level of success in foreign language learning. Also, Yasar (1989) found that being successful in a foreign language leads to increase in positive attitudes. Moreover, Ehrman, Leaver and Oxford (2003), Oxford and Shearin (1994), and Gardner and Tremblay (1995) emphasized that the level of self-efficacy has a significant impact on the learning foreign language motivation.

Though foreign language learning has become a global necessity, there are also some problems in Turkey. They cannot use English effectively, although the majority of students graduating from college (Acat ve Demiral, 2002). According to Atay (2004) and Celebi (2006), the secondary education institutions in which students cannot receive an efficiently foreign language education have a large share in this failure. Aydin and Zengin (2008) point out that it is necessary to determine the problems and solutions in great detail in order to eliminate the problems regarding the learning a foreign language in Turkey. But, they emphasize the number of studies related to the learning a foreign language is quite a few in Turkey.

\section{Literature Review}

\subsection{Self-Regulation Strategies and Foreign Language Learning}

Self-regulation is stated as a vital issue in teaching and learning process (Steffen, 2006; Zimmerman \& Schunk, 2001). Many researchers have conducted on this topic. Because of this, there are different definitions. For instance, Zimmerman (2000) describes it as a process for achieving personal goals where thoughts, feelings and actions of an individual are adjusted into means to the end. It is also identified as a process where the individual is in supervision of his or her motivation and behaviours (Wolters, Pintrich \& Karabenick, 2003). Based on these views, three point arise: students are participate in the learning process readily; they decide their own way of learning; and they control their learning.

There are many self-regulated learning structures (Oxford, 2011; Paris, Byrnes \& Paris, 2001). Pintrich and Garcia (1991) emphasizes that the basic items of the different self-regulated learning models are summarised using three groups: planning, monitoring, and evaluation of the learning outcome. While planning includes goal setting, assessment of internal and external resources, selection of appropriate strategies, and execution, monitoring is an implementation of strategies, tracking their success, and altering strategies as needed. Similar components are involved in a cycle in Zimmerman's (1998) model. In this model, learners evaluate their learning on the onset. Then, they set learning goals and plan appropriate strategies. After carrying out them, they monitor their performance and finish by evaluating learning outcomes.

In the foreign language teaching field, self-regulation has been discussed over the last few decades by many researchers such as Andrade and Bunker (2009), Andrade and Evans (2013), 
Bademcioglu, M., Karatas, H., \& Ergin, A. (2017). The prediction of undergraduates' self-regulation strategies, motivational beliefs, attitudes towards English, and speaking anxiety on foreign language classroom anxiety. Journal of Human Sciences, 14(1), 571-586. doi:10.14687/ihs.v14i1.4132

Gunning and Oxford (2014), Ma and Oxford (2014), and Zimmerman and Risemberg (1997). And, their studies found out that self-regulated learning's efficacy at improving foreign language learning. Andrade and Bunker (2009) state that self-regulation strategies ease foreign language learning as used effectively and regularly. Beside this, they lead to deeper learning and higher performance in language skills such as speaking (Ma \& Oxford, 2014); reading comprehension (Ehrman, 1996); writing (Andrade \& Evans, 2013); and vocabulary (Rasekh \& Ranjbary, 2003).

\subsection{Motivational Beliefs and Foreign Language Learning}

Students' thoughts, attitudes or judgements about the environment around him/her are described as motivational beliefs. They forms motivational beliefs through exposure to learning experiences first-hand (Pintrich, 2000). And, they are required for academic achievement. Also, these beliefs are closely connected with each other (Zimmerman \& Schunk, 2012). It is emphasized by Boekearts (2002) that motivational beliefs can be both positive and negative. Yet, it is quite hard to change them when learners have adopted these beliefs.

Self-efficacy and test anxiety are believed as fundamental elements in motivational beliefs. Selfefficacy which is usually about evaluation by students regarding their future performance may differ in various domains. Because of these, self-efficacy should be evaluated from various aspects (Bandura, 1997). According to the results of their study, Zimmerman, Bandura, and Martinez-Pons (1992) have stated self-efficacy levels in self-regulated learning was equivalent to their academic self-confidence. Pajares (2012) has found out students' selection of activities, effort and perseverance can be predicted through self-efficacy. While hardworking students are those who are self-efficient and they usually put extra effort in learning without being exposure to an external push, the other students who don't have enough confidence in their abilities and skills are extrinsically motivated. And, they set their goals to complete the activity from the drive outside. Apart from these, Pintrich (1999) has determined students enjoyed better academic achievement when they had higher intrinsic motivation.

Test anxiety is another important factor having an effect on motivation. It can be defined as predicting adverse results in exams. And, it includes cognitive, emotional, physiological, and behavioural states (Bembenutty, 2008). Many studies have displayed that poor test performance is characteristic, which is shared by students with test anxiety (Cassady \& Johnson, 2002; Schunk, Pintrich \& Meece, 2008; Zeidner \& Matthews, 2005). Notwithstanding, some researchers such as Schunk, Pintrich, and Meece (2008) have stressed that motivation, self-regulation, and achievement can be improved through controlling test anxiety with appropriate interventions.

According to Gardner (1985), motivation has been broken for language learning into three parts. These are the desire to learn the language, exerting effort and having positive attitudes towards the language learning process. And, there are two types of motivation for language learning: integrative motivation and instrumental motivation. And, if a learner motivates himself/herself, he/she learn for the sake of learning a language. Besides these, many studies as Dornyei (1990), Gardner (2001), and MacIntyre (2002) have revealed that motivation has a significant impact on language learning.

\subsection{Attitude and Foreign Language Learning}

An attitude is described by Smith (1971) as a relatively enduring organization of beliefs around an object or a situation, predisposing one to respond in some preferential manner. It is enduring because it is learned and it can be unlearned. Thanks to being learned, it can be taught. Also, Wenden (1991) underlines it is made up of three components. Those are classified as cognitive which comprises beliefs and perceptions regarding objects, people, or situations, evaluative which 
Bademcioglu, M., Karatas, H., \& Ergin, A. (2017). The prediction of undergraduates' self-regulation strategies, motivational beliefs, attitudes towards English, and speaking anxiety on foreign language classroom anxiety. Journal of Human Sciences, 14(1), 571-586. doi:10.14687/ihs.v14i1.4132

contains likes and dislikes, and behavioural that has learners take on new behaviours such responsibility or confidence which will reflect upon the language learning process.

Smith (1971) states that no student is born liking or disliking foreign language. If the student enter to the class with neutral attitudes about it, or even positive ones, her/his attitudes about foreign language and foreign language learning will be strongly influenced by the situation itself. Also, Csizér and Dörnyei (2005) express that attitude is a significant factor in foreign language learning process. Moreover, Gardner (2005) linked positive attitude towards language learning to motivation by stating that enjoyment will be achieved by the learners who are motivated to learn a foreign language.

Hohenthal (2003) and Kara (2009) indicate that attitudes of learners, other than their opinions and beliefs, will directly reflect upon their behaviours and as a result their performance. Some studies on attitudes towards language learning such as Masgoret and Gardner (2003) and Fakeye (2010) have displayed that there is a strong relationship between attitude and language performance. Also, some others investigated the relations between attitudes and the level of academic achievement (Graham, 2004), and the beliefs and attitudes towards the use of language (Levine, 2003).

\subsection{Foreign Language Speaking Anxiety}

In today's foreign language classrooms, students perform orally in front of a group or participate in group discussions. And, these demanding speaking tasks may affect the learners negatively and they may feel nervous when speaking in the target language (Tanveer, 2007). In accordance with Young (1990), speaking in the target language is stated as the most anxiety producing experience by learners.

There are many researchers who made investigation into students' foreign language speaking anxiety. For instance, Price (1991) found out the learners were anxious about making mistakes in pronunciation. Thanks to this, speaking in front of their peers is a very anxiety provoking activity for the foreign language learners. Also, Koch and Terrell (1991) stated that the most anxiety producing activities are oral presentations, role-playing and defining words. In addition, Saltan (2003) who investigated the foreign language speaking anxiety from the point of students' and teachers' perspectives underlined students experience a certain degree of foreign language speaking anxiety, yet the intensity of it is not disturbingly high.

Balemir (2009) focused on the relationship between proficiency level and degree of foreign language speaking anxiety in English as a foreign language context. This study revealed Turkish EFL university students experience a moderate level of speaking anxiety. Furthermore, the findings of study conducted by Ay (2010) demonstrated learners' anxiety occurs most when they are required to speak without being prepared in advance. The researchers such as Betters (1986), Balemir (2009), Csizer and Dörnyei (2005), Huang (2004) and Pugsley (1991) wanted to explore the effect of gender, which has been asserted to be a leading factor in language learning process, on foreign language speaking anxiety. According to their studies, it was highlighted that gender plays a significant role on foreign language speaking anxiety.

\subsection{Anxiety and Foreign Language Learning}

Harmer (1991) explained some reasons to learn English as a foreign language, for instance, need of advancement in professional life, interest in different cultures, and some other specific purposes. Foreign language learners are expected to become proficient in pronunciation, grammar, vocabulary, discourse, and language skills at the end of the learning process. Gardner and MacIntyre (1993) specified there is a relationship between the learning of English as a foreign 
Bademcioglu, M., Karatas, H., \& Ergin, A. (2017). The prediction of undergraduates' self-regulation strategies, motivational beliefs, attitudes towards English, and speaking anxiety on foreign language classroom anxiety. Journal of Human Sciences, 14(1), 571-586. doi:10.14687/jhs.v14i1.4132

language and the awareness about individual differences, such as the beliefs, attitudes, aptitudes, motivations and affective states of learners. And, language anxiety is defined as one of the individual differences and as an affective state disrupting foreign language achievement. Also, Scovel (1978) defined anxiety as an affective state in which individual perceives danger and feels powerless.

There are many studies being conducted regarding foreign language anxiety. While some of them indicated learners' beliefs about learning a foreign language, teachers' beliefs about teaching a foreign language, classroom procedures and testing as the main sources of anxiety (Young, 1990), the others showed the level of language course, language skills, motivation, and proficiency as being other factors arousing anxiety (Ellis \& Rathbone, 1987; Oxford, 1992; Price, 1991; Sparks \& Ganschow, 1991). But, it can be said prior studies focused on the identification of foreign language anxiety. One of them is the study of Horwitz, Horwitz and Cope (1986). In order to measure communication apprehension, test anxiety, and fear of negative evaluation, they developed the Foreign Language Anxiety Scale (FLAS). According to the results of their study, it was suggested language anxiety is distinct from other types of anxiety.

In Turkey, when the literature is reviewed, it can be seen that related studies conducted are limited. One of these studies was conducted by Dalkilic (2001). It was focused on the relationship between achievement and foreign language anxiety. The findings indicated foreign language anxiety is a significant variable affecting learners' achievement. Also, Batumlu and Erden (2007) examined the relationship between language and anxiety. The results of this study suggested that there is a negative correlation between achievement and anxiety. Yet, it was stated that the proficiency levels of learners and gender do not affect language anxiety. Furthermore, Tuncer and Dogan (2016) made a research so as to identify to what extent the Turkish students' English classroom anxiety affects their academic achievement in English language. And, the findings of the study were revealed that the students' anxiety evolving and ever-increasing during their English prep-education powerfully predicted their academic performance.

\section{Purpose}

Inasmuch as the individual differences, affective factors such as attitudes and motivation of individuals and their anxiety levels are important issues for language learning, the present study is to determine the relationship between self-regulation strategies, motivational beliefs, attitudes, speaking anxiety and foreign language classroom anxiety and to investigate the predictive power of these variables for foreign language classroom anxiety.

\section{Method and material}

4.1. The place and time of the study

The current study was conducted during 2015-2016 academic year at Istanbul Technical University.

\subsection{Population and sample selection}

The research group included 320 male (65.6\%) and 168 female (34.4\%) English preparatory students at Istanbul Technical University. All participants took part in the study voluntarily.

\subsection{Type of the study}

The relational model was used in the current study. 
Bademcioglu, M., Karatas, H., \& Ergin, A. (2017). The prediction of undergraduates' self-regulation strategies, motivational beliefs, attitudes towards English, and speaking anxiety on foreign language classroom anxiety. Journal of Human Sciences, 14(1), 571-586. doi:10.14687/ihs.v14i1.4132

\subsection{The variables}

The self-regulation strategies, motivational beliefs, attitudes, speaking anxiety and FLCA were determined as the variables of the present study.

\subsection{Data collection}

\subsubsection{Data collection method}

Data acquired by means of the applications of Attitude toward English Lesson Scale, Motivated Strategies for Learning Questionnaire, Foreign Language Speaking Anxiety Questionnaire, and Foreign Language Classroom Anxiety Scale was analysed using Kolmogorov-Smirnov normality test, the analysis of Pearson correlation, and a multiple regression analysis via SPSS (Statistical Package for Social Sciences) 21.0 software program. Kolmogorov-Smirnov normality test was used in order to investigate whether the research's independent variables show normality distribution on the scale and their dimensions. The analysis of Pearson correlation was used to define whether there was a relationship between the different variables which are sub-problems of the research and the students' FLCA. A multiple regression analysis was run to determine the predictive power of the research's independent variables on FLCA.

\subsubsection{Data collection tools}

This research is based on the relational model. Motivated Strategies for Learning Questionnaire, Attitudes toward English Lesson Scale, Foreign Language Speaking Anxiety Scale, and Foreign Language Classroom Anxiety Scale were used as the data collection tool. Motivated Strategies for Learning Questionnaire developed by Pintrich and De Groot (1990) and adapted in Turkish by Uredi (2005) consists of 44 items for a total. For each item, respondents were asked to rate themselves on a seven-point Likert scale $(1=$ strongly agree, $7=$ strongly disagree $)$. The questionnaire includes two dimensions: self-regulation strategies and motivational beliefs. In selfregulation strategies dimension, there are two scales. The first one is using cognitive strategies (13 items). And, the second one is self-regulation ( 9 items). There are also three scales in the motivational beliefs dimension: self-efficacy ( 9 items), intrinsic value perception ( 9 items), and test anxiety (4 items).

The original form of Attitudes towards English Scale was Attitudes towards Mathematics and Physics Scale developed by Aiken (1979). The scale was later adapted by Tunc (2003) in Turkish in order to determine the attitudes of students towards English. It consists of 24 items for a total. For each item, respondents were asked to rate themselves on a five-point Likert scale $(1=$ strongly disagree, $5=$ strongly agree). Tunc (2003) highlighted that the statement "neutral" in the original scale was exchanged with the statement "agree somewhat" to reduce the number of participants who has lower interest in relation to others during the rating process. And, it is stated the reliability coefficient was calculated through Cronbach's Alpha and the result was .77.

Foreign Language Speaking Anxiety Questionnaire is developed by Horwitz, Horwitz and Cope (1986) and it is adapted in Turkish by Saltan (2003). Saltan (2003) designed the questionnaire by selecting 18 items which were decided to be directly related to foreign language speaking anxiety from 33 items of original form. The questionnaire is a 5 -graded Likert scale $(1=$ strongly disagree, $5=$ strongly agree). The reliability coefficient was calculated as .91 Cronbach's Alpha (Saltan, 2003).

Foreign Language Classroom Anxiety Scale developed by Horwitz, Horwitz and Cope (1986) and adapted in Turkish by Aydin (2001) consists of 32 items for a total. For each item, respondents were asked to rate themselves on a five-point Likert scale $(1=$ strongly disagree, $5=$ strongly agree). The highest point to be obtained in the Foreign Language Classroom Anxiety Scale was 
Bademcioglu, M., Karatas, H., \& Ergin, A. (2017). The prediction of undergraduates' self-regulation strategies, motivational beliefs, attitudes towards English, and speaking anxiety on foreign language classroom anxiety. Journal of Human Sciences, 14(1), 571-586. doi:10.14687/ihs.v14i1.4132

165 and the lowest point was 32. And, high score indicates high level of foreign language classroom anxiety (FLCA). The reliability coefficient was calculated as .90 Cronbach's Alpha (Aydin, 2001).

\section{Results}

To explore the relationship between self-regulation strategies, motivational beliefs, attitudes, foreign language speaking anxiety and FLCA and to investigate the predictive power of these variables for FLCA, the data was analysed in this section. In this section, it was given the results of these analyses.

Table 1 summarizes the following findings which include descriptive statistics on the research's independent variables.

Table 1. Means, Standard Deviations and Maximum Scores

\begin{tabular}{|c|c|c|c|c|c|c|c|}
\hline Scales & $\begin{array}{c}\text { Sub- } \\
\text { Dimensions }\end{array}$ & $\mathbf{N}$ & Mean & Min. & Max. & $\begin{array}{l}\text { Std. } \\
\text { D. }\end{array}$ & $\begin{array}{l}\text { Std. } \\
\text { Er. }\end{array}$ \\
\hline \multirow[t]{5}{*}{$\begin{array}{l}\text { Motivated Strategies for } \\
\text { Learning Questionnaire }\end{array}$} & $\begin{array}{c}\text { Using cognitive } \\
\text { strategy }\end{array}$ & 488 & 56.60 & 13.00 & 87.00 & 12.12 & .54 \\
\hline & Self-regulation & 488 & 33.29 & 9.00 & 57.00 & 7.20 & .32 \\
\hline & Self-efficacy & 488 & 36.37 & 9.00 & 81.00 & 8.61 & .39 \\
\hline & $\begin{array}{l}\text { Intrinsic value } \\
\text { perception }\end{array}$ & 488 & 41.01 & 9.00 & 63.00 & 9.50 & .43 \\
\hline & Test anxiety & 488 & 12.01 & 4.00 & 28.00 & 5.58 & .25 \\
\hline $\begin{array}{l}\text { Attitude toward English Lesson } \\
\text { Scale }\end{array}$ & & 488 & & & & & \\
\hline $\begin{array}{l}\text { Foreign Language Speaking } \\
\text { Anxiety Scale }\end{array}$ & & 488 & 48.47 & 18.00 & 90.00 & 15.41 & .69 \\
\hline $\begin{array}{c}\text { Foreign Language Classroom } \\
\text { Anxiety Scale }\end{array}$ & & 488 & 88.67 & 32.00 & 157.00 & 21.19 & .96 \\
\hline
\end{tabular}

According to the findings in Table 1, the mean of using cognitive strategies scores of university students is 56.60. And, they get the highest score from using cognitive strategies dimension. The other sub-dimensions, intrinsic value perception (41.01), self-efficacy (36.67), self-regulation (33.29), and test anxiety (12.01) respectively followed each other. Also, the mean of FLCA scores of university students is 48.47 . And, it can be seen that the students receive the maximum 90 and minimum 18 points. Moreover, it can be seen that the mean of FLCA scores of university students is 88.67. And, the students receive the maximum 150 and minimum 32 points.

In Table 2, the findings regarding the correlation analysis on the relationship between university students' FLCA and self-regulation strategies, motivational beliefs, attitudes, and foreign language speaking anxiety are shown. 
Bademcioglu, M., Karatas, H., \& Ergin, A. (2017). The prediction of undergraduates' self-regulation strategies, motivational beliefs, attitudes towards English, and speaking anxiety on foreign language classroom anxiety. Journal of Human Sciences, 14(1), 571-586. doi:10.14687/ihs.v14i1.4132

Table 2. Correlation Analysis among Pre-service Teachers' Academic Procrastination and Personality Traits

\begin{tabular}{|c|c|c|c|c|c|c|c|c|c|}
\hline & & UCS & $\overline{\text { SR }}$ & $\mathrm{SE}$ & IVP & TA & $\bar{A}$ & FLSA & FLCA \\
\hline \multirow[t]{3}{*}{ UCS } & $\mathrm{R}$ & 1 & $.62 * *$ & $.47 * *$ & $.64 * *$ & $.14 * *$ & $.30 * *$ & .01 & .05 \\
\hline & Sig. (2-tailed) & & .00 & .00 & .00 & .00 & .00 & .72 & .24 \\
\hline & $\mathrm{N}$ & 488 & 488 & 488 & 488 & 488 & 488 & 488 & 488 \\
\hline \multirow[t]{3}{*}{ SR } & $\mathrm{R}$ & $.62 * *$ & 1 & $.36 * *$ & $.45^{* *}$ & $.26^{* *}$ & $.18^{* *}$ & .06 & $.12^{* *}$ \\
\hline & Sig. (2-tailed) & .00 & & .00 & .00 & .00 & .00 & .17 & .01 \\
\hline & $\mathrm{N}$ & 488 & 488 & 488 & 488 & 488 & 488 & 488 & 488 \\
\hline \multirow[t]{3}{*}{ SE } & $\mathrm{R}$ & $.47 * *$ & $.36 * *$ & 1 & $.60 * *$ & .04 & $.44^{* *}$ & $-.25 * *$ & $-.25^{* *}$ \\
\hline & Sig. (2-tailed) & .00 & .00 & & .00 & .38 & .00 & .00 & .00 \\
\hline & $\mathrm{N}$ & 488 & 488 & 488 & 488 & 488 & 488 & 488 & 488 \\
\hline \multirow[t]{3}{*}{ IVP } & $\mathrm{R}$ & $.64 * *$ & $.45^{* *}$ & $.60^{* *}$ & 1 & $.08^{*}$ & $.52^{* *}$ & $-.13 * *$ & $-.10^{*}$ \\
\hline & Sig. (2-tailed) & .00 & .00 & .00 & & .05 & .00 & .00 & .02 \\
\hline & $\mathrm{N}$ & 488 & 488 & 488 & 488 & 488 & 488 & 488 & 488 \\
\hline \multirow[t]{3}{*}{ TA } & $\mathrm{R}$ & $.14^{* *}$ & $.26 * *$ & .04 & $.08^{*}$ & 1 & $-.13 * *$ & $.42^{* *}$ & $.48^{* *}$ \\
\hline & Sig. (2-tailed) & .00 & .00 & .38 & .05 & & .00 & .00 & .00 \\
\hline & $\mathrm{N}$ & 488 & 488 & 488 & 488 & 488 & 488 & 488 & 488 \\
\hline \multirow[t]{3}{*}{ A } & $\mathrm{R}$ & $.30^{* *}$ & $.18^{* *}$ & $.44 * *$ & $.52 * *$ & $-.13^{* *}$ & 1 & $-.30 * *$ & $-.33 * *$ \\
\hline & Sig. (2-tailed) & .00 & .00 & .00 & .00 & .00 & & .00 & .00 \\
\hline & $\mathrm{N}$ & 488 & 488 & 488 & 488 & 488 & 488 & 488 & 488 \\
\hline \multirow[t]{3}{*}{ FLSA } & $\mathrm{R}$ & .01 & .06 & $-.25^{* *}$ & $-.13 * *$ & $.42 * *$ & $-.30 * *$ & 1 & $.90^{* *}$ \\
\hline & Sig. (2-tailed) & .72 & .17 & .00 & .00 & .00 & .00 & & .00 \\
\hline & $\mathrm{N}$ & 488 & 488 & 488 & 488 & 488 & 488 & 488 & 488 \\
\hline \multirow[t]{3}{*}{ FLCA } & $\mathrm{R}$ & .05 & $.12^{* *}$ & $-.25^{* *}$ & $-.10^{*}$ & $.48^{* *}$ & $-.33^{* *}$ & $.90^{* *}$ & 1 \\
\hline & Sig. (2-tailed) & .24 & .01 & .00 & .02 & .00 & .00 & .00 & \\
\hline & $\mathrm{N}$ & 488 & 488 & 488 & 488 & 488 & 488 & 488 & 488 \\
\hline
\end{tabular}

* Correlation is significant at the .05 level (2-tailed).

** Correlation is significant at the .01 level (2-tailed).

UCS (Using cognitive strategies), SR (Self-regulation), SE (Self-efficacy), IVP (Intrinsic value perception), TA (Test anxiety), A (Attitude towards English), FLSA (Foreign language speaking anxiety), FLCA (Foreign language classroom anxiety).

Based on the results of correlation analysis in Table 2, there have been found some significant positive and negative correlations between variables. It was found that there is a significant 
Bademcioglu, M., Karatas, H., \& Ergin, A. (2017). The prediction of undergraduates' self-regulation strategies, motivational beliefs, attitudes towards English, and speaking anxiety on foreign language classroom anxiety. Journal of Human Sciences, 14(1), 571-586. doi:10.14687/ihs.v14i1.4132

positive correlation between FLCA and self-regulation $(\mathrm{r}=.12, \mathrm{p}<.01)$, between FLCA and test anxiety $(\mathrm{r}=.48, \mathrm{p}<.01)$, and between FLCA and foreign language speaking anxiety $(\mathrm{r}=.90, \mathrm{p}<.01)$. Also, it could be reported that there is significant negative correlation between FLCA and selfefficacy $(\mathrm{r}=-.25, \mathrm{p}<.01)$, between FLCA and intrinsic value perception $(\mathrm{r}=-.10, \mathrm{p}<.05)$, and between FLCA and attitude towards English $(r=-.33, \mathrm{p}<.01)$. Yet, it was found that there is not significant correlation between FLCA and using cognitive strategies.

According to Table 2, a significant negative correlation was seen between self-efficacy and foreign language speaking anxiety $(\mathrm{r}=-.25, \mathrm{p}<.01)$, between intrinsic value perception and foreign language speaking anxiety $(\mathrm{r}=-.13, \mathrm{p}<.01)$, and between attitude towards English and foreign language speaking anxiety $(\mathrm{r}=-.30, \mathrm{p}<.01)$.

Table 3. The Findings of ANOVA Analysis Regarding the Prediction Level of University Students' Self-Regulation Strategies, Motivational Beliefs, Attitudes, and Foreign Language Speaking Anxiety to their Foreign Language Classroom Anxiety

\begin{tabular}{cccccc}
\hline Model & $\begin{array}{c}\text { Sum of } \\
\text { Squares }\end{array}$ & df & $\begin{array}{c}\text { Mean } \\
\text { Square }\end{array}$ & $\mathbf{F}$ & $\mathbf{p}$ \\
\hline 1 Regression & 181448.52 & 7 & 25921.21 & 404.99 & $.00^{* *}$ \\
Residual & 29506.14 & 481 & 115.44 & & \\
Total & 210954.67 & 488 & 64.00 & & \\
\hline
\end{tabular}

** Regression is significant at the .01 level

In terms of the findings of ANOVA analysis in Table 3, when using independent variables together it is seen that they can predict university students' FLCA significantly $[\mathrm{F}(7 ; 481)=$ 404.99 and $\mathrm{p}<.01]$. Also, the findings on the prediction level of university students' selfregulation strategies, motivational beliefs, attitude towards English, and foreign language speaking anxiety to their FLCA were given in Table 4.

Table 4. The Findings Regarding the Prediction Level of University Students' SelfRegulation Strategies, Motivational Beliefs, Attitude towards English, and Foreign Language Speaking Anxiety to their Foreign Language Classroom Anxiety

\begin{tabular}{ccccc}
\hline $\begin{array}{c}\text { Dependent } \\
\text { Variable }\end{array}$ & $\mathbf{R}$ & $\mathbf{R}^{2}$ & Adjusted $\mathbf{R}^{2}$ & $\begin{array}{c}\text { Std. Error of } \\
\text { the } \\
\text { Estimate }\end{array}$ \\
\hline FLCA & .92 & .86 & .85 & 8.00 \\
\hline
\end{tabular}

Predictors (Independent variables): Self-Regulation Strategies, Motivational Beliefs, Attitude towards English, and Foreign Language Speaking Anxiety

As is seen Table 4, when using all independent variables together it was found that there was a significant correlation $(\mathrm{p}<.01)$ between them $(\mathrm{R}=.92 ; \mathrm{p}<.00)$. The prediction level of university students' self-regulation strategies, motivational beliefs, attitudes, and foreign language speaking anxiety to their FLCA was found .85 (Adjusted $\mathrm{R}^{2}$ ). That is to say, $\% 85$ of university students' FLCA is explained and predicted through self-regulation strategies, motivational beliefs, attitude towards English, and foreign language speaking anxiety. Regression coefficients and their significance level were given in Table 5 . 
Bademcioglu, M., Karatas, H., \& Ergin, A. (2017). The prediction of undergraduates' self-regulation strategies, motivational beliefs, attitudes towards English, and speaking anxiety on foreign language classroom anxiety. Journal of Human Sciences, 14(1), 571-586. doi:10.14687/ihs.v14i1.4132

Table 5. The Findings of Multiple Regression Analysis Regarding the Prediction Level of University Students' Self-Regulation Strategies, Motivational Beliefs, Attitude towards English, and Foreign Language Speaking Anxiety to their Foreign Language Classroom Anxiety

\begin{tabular}{ccccccc}
\hline Model & $\begin{array}{c}\text { Independent } \\
\text { Variables }\end{array}$ & B & Std. E. & Beta & $\mathbf{t}$ & $\mathbf{p}$ \\
\hline 1 & Constant & 33.8 & 3.26 & & 10.35 & $.00^{*}$ \\
& UCS & .06 & .04 & .03 & 1.35 & .17 \\
SR & .08 & .06 & .03 & 1.29 & .19 \\
& SE & -.02 & .05 & -.08 & -3.70 & $.00^{* *}$ \\
& IVP & .09 & .06 & .04 & 1.63 & .10 \\
& TA & .46 & .07 & .12 & 6.03 & $.00^{* *}$ \\
& TUT & -.11 & .03 & -.07 & -3.22 & $.00^{* *}$ \\
& FLSA & 1.13 & .02 & .82 & 40.13 & $.00 * *$ \\
\hline
\end{tabular}

Dependent Variable: FLCA

* Regression is significant at the .05 level

** Regression is significant at the .01 level

The findings in Table 5 shows that there is a significant correlation between university students' self-efficacy, test anxiety, attitude towards English, foreign language speaking anxiety, and FLCA $(\mathrm{p}<.01)$. Yet, it is not confirmed a significant correlation between their using cognitive strategies, self-regulation, and intrinsic value perception dimensions and FLCA ( $p>.01)$. That is to say, while self-efficacy, test anxiety, attitude towards English, and foreign language speaking anxiety are the predictors of university students' foreign language classroom anxiety, using cognitive strategies, self-regulation, and intrinsic value perception dimensions do not contribute to the prediction level of university students' FLCA.

\section{Discussion}

One of the findings of the study is that there is not significant correlation between foreign language classroom anxiety and using cognitive strategies dimension. This finding does not corroborate previous studies that found there is a significant negative relationship between language classroom anxiety and using cognitive strategies (Ghorban Mohammadi, Biria, Koosha, \& Shahsavari, 2013; Martirossian \& Hartoonian, 2015; Shabani, 2015). In addition, Zimmerman (2000) highlighted self-regulatory skills would be of little value if a person would be unable to motivate themselves to utilize them. In this regard, the finding of the current study is in accordance with those of Liu and Chen (2015) and Martirossian and Hartoonian (2015) revealing that there is a significant negative relationship between foreign language classroom anxiety and self-regulation dimension.

Bandura (1997) stated students with low levels of self-efficacy do not feel as if they can meet the goals. Due to this, they become depressed. And, in this study, there is a significant negative relationship between university students' FLCA and self-efficacy dimension. It indicates that students who perceive high level of self-efficacy in themselves experience lower level of FLCA. This finding supports the results of a studies conducted by Yuh-show (2001), Anyadubalu (2010), 
Bademcioglu, M., Karatas, H., \& Ergin, A. (2017). The prediction of undergraduates' self-regulation strategies, motivational beliefs, attitudes towards English, and speaking anxiety on foreign language classroom anxiety. Journal of Human Sciences, 14(1), 571-586. doi:10.14687/ihs.v14i1.4132

and Cubukcu (2008). Also, in the present study, there is significant negative correlation between FLCA and intrinsic value perception dimension. This result were supported by Nishitani and Matsuda (2009; 2011).

Another finding of the study is that there was a positive relationship between university students' FLCA and test anxiety dimension in this study. This result is again in contrast with some studies in the literature. For example, while some researchers such as Aida (1994) and MacIntyre and Gardner (1989) suggested test anxiety was not related to FLCA, Salehi and Marefat (2014) found out that there was a positive relationship between them.

Hussain, Shahid and Zaman (2011) stated attitude and language learning have close link and influence upon each other. In the present study, there exists a negative correlation between university students' FLCA and attitude towards English language learning. This result were supported by Stark and Paltridge (1996) who suggested that there existed a strong negative relationship between them. Negative relationship between FLCA and language attitude show that low language attitude might support high level of FLCA.

In the current study, it was found out that there was a positive relationship between university students' FLCA and foreign language speaking anxiety. It is encountered often in the literature. And, since the preliminary study of Horwitz, Horwitz and Cope (1986) in this respect, many studies (Awan Azher, Anwar, \& Naz, 2010; Demirdas \& Bozdogan, 2013; Dogan \& Tuncer, 2016; Proulx, 1991) have reported this result.

The regression analysis indicated that self-efficacy, test anxiety, attitude towards English, and foreign language speaking anxiety significantly predict students' FLCA in the present study. The self-efficacy dimension was found to be statistically significant at $\mathrm{p}=.05$ with a Beta value of -.08. The test anxiety dimension was found to be statistically significant at $\mathrm{p}=.05$ with a Beta value of .12. The attitude towards English was found to be statistically significant at $p=.05$ with a Beta value of -.17. And, foreign language speaking anxiety was found to be statistically significant at $\mathrm{p}=.05$ with a Beta value of .82. Yet, the study conducted by Tóth (2007) revealed that motivational beliefs, attitude, and foreign language speaking anxiety do not significantly predict students' FLCA. And, this result differs from the results found in the present study.

\section{Conclusion and recommendations}

The aim of the present study was to examine the relationship between self-regulation strategies, motivational beliefs, attitudes, speaking anxiety and FLCA and to investigate the predictive power of these variables for FLCA. The findings revealed that there is not significant correlation between FLCA and using cognitive strategies dimension. While there is a significant positive correlation between FLCA and self-regulation, test anxiety dimensions and foreign language speaking anxiety, there is significant negative correlation between FLCA and self-efficacy, intrinsic value perception dimensions and attitude towards English. Also, self-efficacy, test anxiety, attitude, and foreign language speaking anxiety are predictors of the university students' FLCA.

Variables like self-regulation strategies, motivational beliefs, anxiety, and attitude may be subject to certain factors. Thus, teachers should try to reduce both foreign language speaking anxiety and test anxiety by creating supportive atmosphere in class, encourage students' involvement in class activities, and teach some anxiety-reducing strategies to the students. Thanks to these, they can enhance students' foreign language learning.

As the findings of the study take into consideration, it can be suggested some ideas for the researchers for further research. For instance, this study investigated and evaluated the 
Bademcioglu, M., Karatas, H., \& Ergin, A. (2017). The prediction of undergraduates' self-regulation strategies, motivational beliefs, attitudes towards English, and speaking anxiety on foreign language classroom anxiety. Journal of Human Sciences, 14(1), 571-586. doi:10.14687/jhs.v14i1.4132

information of the students by the questionnaires. For this reason, more qualitative data may be collected through observation or interview techniques. Also, the current study conducted with the participation of 488 English preparatory students. Because of this, further studies may be carried out with a larger sample group.

\section{References}

Acat, M. B., \& Demiral, S. (2002). Turkiye'de yabanci dil ogreniminde motivasyon kaynaklari ve sorunlari. Kuram ve Uygulamada Egitim Yonetimi Dergisi, 8(31); 312-329.

Aida, Y. (1994). Examination of Horwitz, Horwitz and Cope's construct of foreign language anxiety: The case of students of Japanese. The Modern Language Journal, 78(2); 155-68.

Aiken, L. R. (1979). Attitudes toward mathematics and science in Iranian middle schools. School Science and Mathematics, 79(3); 229-234.

Anyadubalu, C. C. (2010). Self-efficacy, anxiety, and performance in the English language among middle-school students in English language program in Satri Si Suriyothai School, Bangkok. International Journal of Social, Behavioural, Educational, Economic, Business and Industrial Engineering, 4(3).

Andrade, M. S., \& Bunker, E. L. (2009). A model for self-regulated distance language learning. Distance Education, 30; 47-61.

Andrade, M. S., \& Evans, N. W. (2013). Principles and practices for response in second language writing: Developing self-regulated learners. New York: Taylor and Francis.

Atay, D. (2004). Ingilizce ogretmenlerinin motivasyon stratejileri. Hasan Ali Yucel Egitim Fakultesi Dergisi, 1(1); 99-108.

Awan, R., Azher, M., Anwar, M., N., \& Naz, A. (2010). An investigation of foreign language classroom anxiety and its relationship with students' achievement. Journal of College Teaching and Learning, 7(11); 33-40.

Ay, S. (2010). Young adolescent students' foreign language anxiety in relation to language skills at different levels. The Journal of International Social Research, 3(11); 83-92.

Aydin, B. (2001). Konusma ve yazma derslerinde yabancı dil ögrenimindeki kaygz nedenleri. Doctoral dissertation. Anadolu University.

Aydin, S., \& Zengin, B. (2008). Yabanc1 dil egitiminde kayg1: bir literatur ozeti. The Journal of Language and Linguistic Studies, 4(1); 81-94.

Balemir, S. H. (2009). The sources of foreign language speaking anxiety and the relationship between proficiency level and the degree of foreign language speaking anxiety. Unpublished master's thesis. Bilkent University.

Bandura, A. (1997). Self-efficacy: The exercise of control. New York: Worth Publishers.

Batumlu, D. Z., \& Erden, M. (2007). The relationship between foreign language anxiety and English achievement of Yildiz Technical University of foreign languages preparatory students. Egitimde Kuram ve Uygulama, 3(1); 24-38.

Bembenutty, H. (2008). Self-regulation of learning and test anxiety. Pyschology Journal, 5(3); 122 139.

Betters, J. (1986). Do boys really think languages are just girl-talk? Modern Languages, 6(2); 75-79.

Boekearts, M. (2002). Bringing about change in the classroom: Strengths and weaknesses ofthe self-regulated learning approach-EARLI presidential address, 2001. Learning and Instruction, 12; 589-604.

Cassady, J. C., \& Johnson, R. E. (2002). Cognitive test anxiety and academic performance. Contemporary Educational Psychology 27, 270-295. View article: DOI:10.1006/ceps.2001.1094 
Bademcioglu, M., Karatas, H., \& Ergin, A. (2017). The prediction of undergraduates' self-regulation strategies, motivational beliefs, attitudes towards English, and speaking anxiety on foreign language classroom anxiety. Journal of Human Sciences, 14(1), 571-586. doi:10.14687/jhs.v14i1.4132

Csızér, K., \& Dörnyei, Z. (2005). The internal structure of language learning motivation and its relationship with language choice and learning effort. The Modern Language Journal, (89); 1936.

Celebi, M. D. (2006). Türkiye'de anadili egitimi ve yabanc1 dil ogretimi. Erciyes Universitesi Sosyal Bilimler Enstitusu Dergisi, $21(2) ; 285-307$.

Çubukçu, F. (2008). A Study on the correlation between self-efficacy and foreign language learning anxiety. Journal of Theory and Practice in Education, 4(1); 148-158.

Dalkilic, N. (2001). An investigation into the role of anxiety in second language learning. Unpublished doctoral dissertation. Cukurova University.

Demirdas, O., \& Bozdogan, D. (2013). Foreign Language Anxiety and Performance of Language Learners in Preparatory Classes. Turkish Journal of Education, 2(3); 4-13.

Dogan, Y., \& Tuncer, M. (2016). Examination of Foreign Language Classroom Anxiety and Achievement in Foreign Language in Turkish University Students in Terms of Various Variables. Journal of Education and Training Studies, 4(5).

Dörnyei, Z. (1990). Conceptualizing motivation in foreign language learning. Language Learning, 40; 46-78.

Dörnyei, Z., \& Csizer, K. (2002). Some dynamics of language attitudes and motivation: Results of a longitudinal nationwide survey. Applied Linguistics, 23; 421-462.

Ehrman, M. (1996). An exploration of adult language learner motivation, self-efficacy and anxiety. In: R.L. Oxford (Ed.), Language learning motivation: Pathways to the new century (pp. 81-103). Honolulu, HI: University of Hawaii Press.

Ehrman, M. E., Leaver, B. L., \& Oxford, R. L. (2003) A brief overview of individual differences in second language learning. System, 31; 313-330.

Ellis, R. (1994). The study of Second Language Acquisition. Oxford: Oxford University Press.

Ellis, R., \& Rathbone, M. (1987). The acquisition of German in a classroom context. Mimeograph. London: Ealing College of Higher Education.

Fakeye, O. (2010). Students' personal variables as correlates of academic achievement in English as a second language in Nigeria. Journal of Social Sciences, 22(3); 205-211.

Gardner, R. (1985). Social psychology and second language learning. The role of attitudes and motivation. London: Edward Arnold.

Gardner, R. (2001). Correlation, causation, motivation, and second language acquisition. Canadian Psychology, 41; 10-24.

Gardner, R. C (2005). Integrative motivation and second language acquisition. Paper presented at the Canadian Association of Applied Linguistics, London, Ontario, Canada.

Gardner, R. C., \& MacIntyre, P. D. (1993). On the measurement of affective variables in second language learning. Language Learning, 43; 157-194.

Gardner, R. C., \& Tremblay, P. F. (1995). On motivation: Measurement and conceptual considerations. Modern Language Journal, 78; 524-527.

Ghorban Mohammadi, E., Biria, R., Koosha, M., \& Shahsavari, A. (2013). The relationship between foreign language anxiety and language learning strategies among university students. Theory and Practice in Language Studies, 3(4); 637-646. View article: DOI: 10.4304/tpls.3.4.637-646.

Graham, J. (2004). Giving up on Modern Foreign Languages? Students' perceptions of learning French. The Modern Language Journal, 88; 171-191.

Gunning, P., \& Oxford, R. L. (2014). Children's learning strategy use and the effects of strategy instruction on success in learning ESL in Canada. System, 43; 82-100.

Harmer, J. (1991). The practice of English language teaching. New York: Longman.

Hohenthal, A. (2003). English in India: Loyalty and attitudes. Language in India, 1-107.

Horwitz, E. K., Horwitz, M. B., \& Cope, J. (1986). Foreign language classroom anxiety. Modern Language Journal, 70(2); 125-132. 
Bademcioglu, M., Karatas, H., \& Ergin, A. (2017). The prediction of undergraduates' self-regulation strategies, motivational beliefs, attitudes towards English, and speaking anxiety on foreign language classroom anxiety. Journal of Human Sciences, 14(1), 571-586. doi:10.14687/jhs.v14i1.4132

Huang, H. (2004). The relationship between learning motivation and speaking anxiety among EFL non-English major freshmen in Taiwan. Unpublished master's thesis. Chaoyang University of Technology.

Hussain, M. A., Shahid, S., \& Zaman, A. (2011). Anxiety and attitude of secondary school students towards foreign language learning. Procedia - Social and Behavioral Sciences, 29; 583 590.

Kara, A. (2009). The effect of a learning theories unit on students' attitudes towards learning. Australian Journal of Teacher Education, 34(3); 100-113.

Koch, A. S. \& Terrell T. D. (1991). Affective reactions of foreign language students to natural approach activities and teaching procedures. In E. K. Horwitz \& D. J. Young (Eds.), Language anxiety (pp. 109-125). London: Prentice Hall International.

Levine, G. (2003). Student and Instructor Beliefs and attitudes about target language use, first language use and anxiety: Report of a questionnaire study. Modern Language Journal, 87(3); 343-364.

Liu, H. J., \& Chen, C. W. (2015). A comparative study of foreign language anxiety and motivation of academic and vocational-track high school students. English Language Teaching, 8(3); 193-204. View article: DOI: 10.5539/elt.v8n3p193.

Ma, R., \& Oxford, R. L. (2014). A diary study focusing on listening and speaking: The evolving interaction of learning styles and learning strategies in a motivated, advanced ESL learner. System, 43; 101-113.

MacIntyre, P. (2002). Motivation, anxiety and emotion in second language acquisition. In: P. Robinson, Individual differences in second language acquisition (s. 45-68). Amsterdam: John Benjamins.

MacIntyre, P. D., \& Gardner, R. C. (1989). Anxiety and second language learning: Toward a theoretical clarification. Language Learning. 39(2); 251-75.

MacIntyre, P. D. \& Gardner, R. C. (1991). Methods and results in the study of anxiety and language learning: A review of literature. Language Learning, 41; 85-117.

Martirossian, A., \& Hartoonian, A. (2015). Lowering foreign language anxiety through self regulated learning strategy use. English Language Teaching, 8(12).

Masgoret, A., \& Gardner, R. (2003). Attitudes, motivation, and second language learning: Ameta analysis of studies conducted by Gardner and associates. Language Learning, 53; 167-210.

Mitchell, R. \& Myles, F. (1998). Second Language Learning Theories. London: Edward Arnold.

Nishitani, M., \& Matsuda, T. (2009). A consideration of the interaction of languages anxiety and the learning strategy. Proceedings of World Conference on E-Learning 2009 (pp. 1853-1860).

Nishitani, M., \& Matsuda, T. (2011). The relationship between language anxiety, interpretation of anxiety, intrinsic motivation and the use of learning strategies. US China Education Review B 3, 438-446.

Oxford, R. (1992). Who are our students? A synthesis of foreign and second language research on individual differences with implications for instructional practices. TESL Canada Journal, 9; 30-49.

Oxford, R. (1994). Anxiety and the language learner: New insights. Jane, A. (Ed.), Affect In Language Learning. Cambridge University Press, 58-67.

Oxford, R. L. (2011). Teaching and researching language learning strategies. Harlow: Pearson Longman.

Oxford, R. L., \& Shearin, J. (1994). Language Learning Motivation: Expanding the Theoretical Framework. The Modern Language Journal, 78(1); 12-28.

Pajares, F. (2012). Motivational role of self-efficacy beliefs in self-regulated learning. In: D. Schunk, \& B. Zimmerman, Motivation and self-regulated learning: Theory, research, and applications (s. 111-141). New York: Lawrence Erlbaum Associates. 
Bademcioglu, M., Karatas, H., \& Ergin, A. (2017). The prediction of undergraduates' self-regulation strategies, motivational beliefs, attitudes towards English, and speaking anxiety on foreign language classroom anxiety. Journal of Human Sciences, 14(1), 571-586. doi:10.14687/jhs.v14i1.4132

Paris, S. G., Byrnes, J. P., \& Paris, A. H. (2001). Constructing theories, identifies, and actions of self-regulated learners. In: B. J. Zimmerman \& D. H. Schunk (Eds.), Self-regulated learning and academic achievement: Theoretical perspectives (pp. 253-288). Mahwah, NJ: Lawrence Erlbaum.

Pintrich, P. (1999). The role of motivation in promoting and sustaining self-regulated learning. International Journal of Educational Research, 31; 459-470.

Pintrich, P. (2000). The role of goal orientation in self-regulated learning. In: M. Boekaerts, P. Pintrich, \& Z. M, Handbook of self-regulation (s. 451-502). San Diego, CA: Academic Press.

Pintrich, P. R., \& Garcia, T. (1991). Student goal orientation and self-regulation in the classroom. In: M. L. Maehr \& P. R. Pintrich (Eds.), Advances in motivation and achievement: Goals and self-regulatory processes (pp. 371-402). Greenwich, CT: JAI Press.

Pintrich, P., \& Groot, E. D. (1990). Motivational and self-regulated learning components of classroom academic performance. Journal of Educational Psychology, 82(1); 33-40.

Price, M. L. (1991). The Subjective experience of foreign language anxiety: Interviews with highly anxious students. In E. K. Horwitz \& D. J. Young (Eds.), Language anxiety, (pp. 101 108). Englewood Cliffs, NJ: Prentice Hall.

Proulx, P. (1991). Anxiety in language learning: Recognition and prevention. Canadian Journal of Native Education, 18; 53-64.

Pugsley, J. (1991). Language and gender in the EFL classroom. The Teacher Trainer, 5(1); 27-29.

Rasekh, Z. E., \& Ranjbary, R. (2003). Metacognitive strategy training for vocabulary learning. TESL-EJ, 7; 1-17.

Rossiter, M. J. (2003) The effects of affective strategy training in the ESL classroom. TESLEJ 7(2). For online document: http://writing.berkeley.edu/TESL-EJ/ej26/a2.html.

Salehi, M., \& Marefat, F. (2014). The Effects of Foreign Language Anxiety and Test Anxiety on Foreign Language Test Performance. Theory and Practice in Language Studies, 4(5); 931 940.

Saltan, F. (2003). EFL speaking anxiety: How do students and teachers perceive it? Unpublished master's thesis, Middle East Technical University.

Scovel, T. (1978). The effect on foreign language learning: A review of the anxiety research. Language Learning, 28; 129-42.

Sparks, R. L., \& Ganschow, L. (1991). Foreign language learning differences: affective or native language aptitude differences? Modern Language Journal, 75; 3-16.

Starks, D., \& Paltridge, B. (1996). A note on using sociolinguistic methods to study non-native attitudes towards English. World Englishes, 15(2); 217-224.

Steffen, K. (2006). Self-regulated learning in technology-enhanced learning environments: Lessons of European reviews. European Journal of Education, (41); 353-379.

Schunk, D., Pintrich, P., \& Meece, J. (2008). Motivation in education: Theory, research andapplication. Upper Saddle River: NJ: Merrill/Prentice Hall.

Shabani, M. B. (2015). On the relationship between foreign language anxiety and language learning strategies among Iranian EFL learners. International Journal of Educational Investigations, 2(2); 9-23.

Smith, A. N. (1971). The importance of attitude in foreign language learning. Modern Language Journal, 55(2); 83-88.

Tanveer, M. (2007). Investigations of the factors that cause language anxiety for ESL/EFL learners in learning speaking skills and the influence it casts on communication in the target language. Unpublished master's thesis. University of Glasgow, Scotland.

Tóth, Z. (2007). Predictors of foreign-language anxiety: Examining the relationship between anxiety and other individual learner variables. In J. Horváth \& M. Nikolov (Eds.), UPRT 2007: Empirical studies in English applied linguistics (pp. 123-148). 
Bademcioglu, M., Karatas, H., \& Ergin, A. (2017). The prediction of undergraduates' self-regulation strategies, motivational beliefs, attitudes towards English, and speaking anxiety on foreign language classroom anxiety. Journal of Human Sciences, 14(1), 571-586. doi:10.14687/jhs.v14i1.4132

Tunc, O. (2003). Use of language learning strategies in relation to student characteristics at Baskent University. Unpublished master's thesis. Orta Dogu Teknik Universitesi Sosyal Bilimler Enstitusu, Ankara.

Tuncer, M., \& Dogan, Y. (2015). Effect of foreign language classroom anxiety on Turkish university students' academic achievement in foreign language learning. Journal of Education and Training Studies, 3(6); 14-19. View article: DOI: 10.11114/jets.v3i6.998.

Uredi, I., \& Uredi, L. (2005). Ilkogretim 8. sinif ogrencilerinin oz-duzenleme stratejileri ve motivasyonel inanclarinin matematik basarisini yordama gucu. Mersin Universitesi Egitim Fakultesi Dergisi, 1(2); 250-260.

Wenden, A. (1991). Learner strategies for learner autonomy. London: Prentice Hall.

Wolters, C. A., Pintrinch, P. R., \& Karabenick, S. A. (2003). Assessing academic self-regulated learning. Indicators of Positive Development: Definitions, Measures, and Prospective Validity. Washington, DC.

Yasar, S. (1989). Uzaktan ogretim surecindeki ogrencilerin yabanc1 dil ogretimine iliskin tutumlar1. AU Egitim Fakultesi Dergisi, 227-233.

Young, D. J. (1990). An investigation of students' perspectives on anxiety and speaking. Foreign Language Annals, 23(6); 539-553.

Yuh-show, C. (2001). Learners' beliefs and second language anxiety. Concentric: Studies in English Literature and Linguistics, 27(2); 75-90.

Zeidner, M., \& Matthews, G. (2005). Evaluation anxiety: Current theory and research. In: A. Elliott, \& C. Dweck, Handbook of competence and motivation (s. 141-166). New York: Guilford Press.

Zimmerman, B. J. (1998). Academic studying and the development of personal skill: A self regulatory perspective. Educational Psychologist, 33; 78-86.

Zimmerman, B. (2000). Attaining self-regulation: A social cognitive perspective. In: M. Boekarts, P. Pintrich, \& M. Zeidner, Handbook of self-regulation (s. 13-39). San Diego, CA: Academic Press.

Zimmerman, B., Bandura, A., \& Martinez-Pons, M. (1992). Self-motivation for academic attainment: The role of self-efficacy beliefs and personal goal setting. American Educational Research Journal, 29; 663-676.

Zimmerman, B. J., \& Risemberg, R. (1997). Becoming a self-regulated writer: A social cognitive perspective. Contemporary Educational Psychology, 22; 73-101.

Zimmerman, B., \& Schunk, D. (2001). Self-regulated learning and academic achievement. New York: Springer-Verlag. 